\title{
РЕЗЕРВНИЙ КАПІТАЛ: ЕКОНОМІКО-ПРАВОВЕ ЗАБЕЗПЕЧЕННЯ ФОРМУВАННЯ І ВИКОРИСТАННЯ
}

\begin{abstract}
В статті розглянуто економічний зміст, а також порядок формування резервного капіталу 3 урахуванням вимог чинного нормативно-правового забезпечення. Огрунтовано необхідність і переваги наявності резервного капіталу для підприємства. Доведена відмінність резервного капіталу від інших видів резервів, з якими часто прирівнюється, а саме резерву сумнівних боргів і резервів на відпустки, гарантійні витрати тощо. Проаналізовано дозволені чинним законодавством напрямки використання резервного капіталу. Одержані результати підтверджують, щзо створення резервного капіталу дозволяє підприємству покращити структуру власного капіталу, кредитоспроможність $і$ фінансовий стан загалом.
\end{abstract}

Ключові слова: власний капітал, резервний капітал, відрахування на поповнення, використання, мінімальний розмір

Постановка проблеми. Традиційно вважається, що результативність діяльності підприємства визначається величиною заробленого прибутку. Але сам факт наявності прибутку не обов'язково свідчить про ефективність роботи. Дуже важливо, чи $\epsilon$ достатньою сума заробленого прибутку, як підприємство розпоряджається ним, i, загалом, наскільки добре і правильно здійснює управління всім власним капіталом. Зміна величини власного капіталу відображає ефективність як операційної, так і інших видів діяльності.

Власний капітал $\epsilon$ підгрунтям фінансової незалежності підприємства i базою для формування його активів. Внаслідок підприємницької діяльності власний капітал або нарощується, або «проїдається». Лише за умови збереження i прирощення власного капіталу можна говорити про прибутковість, залучати кошти інвесторів. Інвестори вкладуть свої кошти в підприємство тільки в тому випадку, коли будуть зацікавлені тим відсотком, що пропонує

(C) Савчук Тетяна Василівна, к.е.н., доц., доцент кафедри обліку i аудиту, Івано-Франківський національний технічний університет нафти і газу, м. Івано-Франківськ, тел.: 034727117 email: oa@nung.edu.ua

Негрич Інна Михайлівна, к.е.н., доц., доцент кафедри обліку i аудиту, Івано-Франківський національний технічний університет нафти i газу, м. Івано-Франківськ, тел.: 0342727117 email: oa@nung.edu.ua

Побігун Сергій Андрійович, к.е.н., доц., доцент кафедри маркетингу i контролінгу, ІваноФранківський національний технічний університет нафти і газу, м. Івано-Франківськ, тел.: 0342725851, email: mik_ineu@ukr.net; підприємство, i за відсутності сумнівів в поверненні вкладеного фінансування.

Додатковою гарантією сплати підприємством своїх боргів для кредиторів $\epsilon$ наявність резервного капіталу. Але далеко не всі підприємства, та навіть і науковці, зважають на важливість i необхідність його формування. Тому дослідження економічного змісту резервного капіталу і відображення в обліку операцій з ним є необхідними і актуальними.

Аналіз останніх досліджень і публікацій Процес формування та використання власного капіталу загалом i окремих його складових досліджувалися в працях таких визнаних вітчизняних вчених, як Ф.Ф. Бутинець, С.Ф. Голов, Г.Г. Кірейцев, В.К.Орлова, М.С. Пушкар, В.Ф. Палій, В.В. Сопко, а також Л.В. Безкоровайна, О.Н.Коркушко, Г.Б.Машлій, Н.М. Воськало, В.І. Воськало, О.П. Левченко та ін. Але, якщо власному капіталу загалом присвячено багато публікацій, то питання призначення і економічного змісту резервного капіталу як складової власного досліджені недостатньо. Зокрема деякі автори прирівнюють резервний капітал до інших видів резервів (резерву сумнівних боргів, резерву відпусток тощо), 3 чим в жодному разі не можна погодитись.

Існуючі теоретичні i практичні наукові розробки щодо економічної суті резервного капіталу мають вагоме значення для розвитку вітчизняної теорії капіталу, проте практичне використання свідчить, що вони потребують подальшого дослідження.

Формулювання цілей статті Основною метою даного дослідження $є$ удосконалення визначення економічної суті i призначення резервного капіталу суб' єктів господарювання на 
основі аналізу нормативно-правового забезпечення і існуючих підходів, обгрунтування переваг від його створення для підприємства, конкретизації можливих напрямів використання.

Опис основного матеріалу дослідження Насамперед, визначимось 3 терміном. Як в науковій літературі, так і в окремих нормативних актах відсутній єдиний підхід. Вживається як термін «резервний капітал», так i «резервний фонд». Так, в Господарському кодексі [2], Законі України «Про господарські товариства» [5] мова йде про резервний (страховий) фонд, а в новішому Законі України «Про акціонерні товариства» [4] вже вказується на формування резервного капіталу. Ми вважаємо ці терміни синонімами, відмінностей між ними немає. Просто раніше вживався термін «фонд» як залишок командно-адміністративної економіки, сучасним же терміном є «капітал».

Формування резервного капіталу може бути як обов'язком підприємства, так і створюватись ним добровільно. Зразу зазначимо, що в даному дослідженні нами розглядаються суб'єкти господарювання (як приватні підприємства, так і господарські товариства), поза межами аналізу залишаються банки, державні підприємства i бюджетні установи.

Законодавство містить вимогу обов'язковості нарахування резервного капіталу тільки для:

- акціонерних товариств - в розмірі, не менше ніж 15 відсотків статутного капіталу (ч.1 ст. 19 Закону України «Про акціонерні товариства» № 514-VI від 17.09.2008 р. [4]);

- інших видів товариств - у розмірі, не менше 25 відсотків статутного (складеного) капіталу (ст. 14 Закону України «Про господарські товариства» № 1576-ХІІ від 19.09.1991р. [5]).

Bci інші підприємства можуть формувати резервний капітал добровільно.

Незалежно від того, чи робить підприємство цей вибір добровільно, чи зобов'язане так чинити, всі питання, пов'язані з особливостями формування, максимальної величини і напрямків використання, повинні бути детально розкриті в статуті (для акціонерних товариств, товариств 3 обмеженою і додатковою відповідальністю), чи засновницькому договорі (повного i командитного товариства) (надалі - установчих документах) 3 урахуванням вимог чинного законодавства. Відсутність необхідних даних щодо резервного капіталу в установчих документах тих підприємств, які зобов'язані його створювати, $є$ підставою для відмови у державній реєстрації такого підприємства.

Щодо кожної дії (поповнення резервного капіталу чи його використання) повинно бути окреме рішення загальних зборів учасників підприємства. Тобто навіть якщо в установчих документах деталізовано, на яку суму створюється резервний капітал, як i коли, щороку слід закріплювати ці дії відповідними рішеннями 3 занесенням в Протокол загальних зборів.

Законодавство [4, 5] зазначає, що формується резервний капітал шляхом щорічних відрахувань від чистого прибутку або за рахунок нерозподіленого прибутку. В Господарському кодексі [2, ч. 4 ст. 87] вказується про відрахування 3 прибутку (без конкретизації, якого саме). Формально вибір ніби $є$, але це не зовсім так. Чистий прибуток $є$ тільки базою для розрахунку відрахувань на поповнення резервного капіталу. Поповнення здійснюється за рахунок нерозподіленого прибутку.

Періодичність поповнень ніде не визначена. Теоретично ці операції прив'язуються до періодичності складання фінансової звітності i розрахунку фінансового результату діяльності підприємства. В свою чергу, фінансова звітність в обов'язковому порядку складається за результатами року, хоча підприємство має право на складання і проміжної - за результатами меншого проміжку часу: місяць, квартал... Сталою $є$ практика, що відрахування на поповнення резервного капіталу проводять за результатами календарного року. По завершенню року складається фінансова звітність, в якій розраховується зароблений чистий прибуток за цей рік. Не пізніше як 30 квітня року, наступного за звітним, скликаються загальні збори учасників підприємства, які ознайомлюються 3 показниками фінансової звітності за рік і приймають рішення про шляхи використання заробленого прибутку. Будь-яке використання прибутку $\epsilon$ виключним правом загальних зборів учасників підприємства. Після прийняття відповідного рішення - частина прибутку спрямовується на поповнення резервного капіталу. На основі цього рішення учасників керівник видає відповідний наказ про використання прибутку на поповнення резервного капіталу. Сума такого поповнення залежить від зазначеної в установчих документах величини, але не менше 5 \% заробленого чистого прибутку за звітний період. Ця операція буде проведена не раніше, ніж збори учасників затвердять фінансову звітність після закриття звітного періоду, тому i виходить, що поповнення резервного капіталу проводиться уже з нерозподіленого прибутку.

Якщо в установчих документах підприємства зазначено про формування резервного капіталу поповнення проводять щороку без винятків до тих пір, до поки не буде накопичена необхідна 
сума. Єдиний виняток: якщо за звітний період підприємство спрацювало збитково - база для відрахувань на поповнення резервного капіталу відсутня (навіть в тому випадку, якщо необхідна величина цього виду капіталу ще не сформована).

Величина резервного і статутного капіталу чітко взаємопов'язані. На відміну від статутного капіталу, який в основній сумі, зазвичай, формується на момент створення підприємства, резервний капітал формується в ході подальшої діяльності. Подальші періодичні поповнення здійснюються до тих пір, доки там не накопичиться необхідна максимальна величина. Максимальна величина теж вибирається підприємством самостійно i вказується в установчих документах (3 урахуванням мінімально допустимої, яка зазначалась уже раніше). Якщо підприємство формує резервний капітал добровільно, мінімальних обмежень може не дотримуватись.

Після досягнення заданого рівня подальші відрахування на поповнення резервного капіталу не проводяться. Надалі величина резервного капіталу залишається без змін до тих пір, поки не виникне потреба його використати, чи до установчих документів не будуть внесені зміни, що вимагатимуть пропорційно змінити величину цього виду капіталу.

Прив'язку величини резервного капіталу пропорційно до статутного багато науковців вважають не дуже доречною [1, с.307], і ми підтримуємо цю позицію. Статутний капітал після формування в момент створення підприємства дуже часто надалі не змінюється. Законодавчі вимоги щодо мінімально необхідного його рівня є тільки у відношенні до акціонерних товариств - 1250 мінімальних заробітних плат, виходячи із ставки мінімальної заробітної плати, що діє на момент створення (реєстраціі) акціонерного товариства [4, ст.14]. Bci інші 3 аналізованих суб'єктів господарювання мають право самостійно визначати ту суму, що вноситься засновниками. Це може бути і надто мала величина. 3 часом внесена сума може не змінюватись. I, якщо припустимо, на початку діяльності статутний капітал був невеликий, то за багато років функціонування підприємства ця вартість може повністю знецінитись і знівелюватись. В цьому випадку, формуючи резервний капітал пропорційно від невеликого статутного капіталу, одержана сума буде мізерна і не виконуватиме свого призначення. Ніяких процедур дооцінювання чи індексування ні статутного капіталу, ні резервного чинне законодавство не передбачає, а вони були б дуже доречними.
Існує помилкове твердження, що резервний капітал створюється для страхування підприємства від майбутніх збитків, форс мажору, покриття непередбачених витрат тощо. Використовуватись резервний капітал може винятково на цілі, які передбачені чинним законодавством. Але чітко визначені напрямки використання резервного капіталу законодавство містить тільки для акціонерних товариств. Зокрема, ст.19 Закону України «Про акціонерні товариства» [4] зазначає, що резервний капітал використовується для:

- покриття збитків,

- виплати дивідендів за привілейованими акціями,

- інші напрямки використання, які можуть бути передбачені законодавством.

Інші суб'єкти господарювання, очевидно, 3 цими напрямами повинні визначитись самостійно (взявши за основу наведені) i зафіксувавши їх в своїх установчих документах.

На нашу думку, даний перелік $\epsilon$ цілком достатній.

Таким чином, використати резервний капітал на покриття непередбачених витрат можна буде тільки в тому випадку, якщо вони призведуть до збитків підприємства і загальні збори учасників приймуть рішення здійснити ї покриття за рахунок резервного капіталу. Інакше резервний капітал використати на відшкодування якихось разових витрат не вдасться. Саме використання резервного капіталу на покриття збитків $\epsilon$ найбільш реальним напрямком використання.

Використати резервний капітал на виплату дивідендів за привілейованими акціями зможе тільки акціонерне товариство, що емітувало не тільки прості, але і привілейовані акції, але тільки в тому випадку, якщо для цих цілей виявиться недостатньо величини нерозподіленого прибутку і товариство не створювало спеціального фонду для виплати дивідендів за привілейованими акціями, порядок формування i використання якого визначено рішенням Державної комісії з цінних паперів і фондового ринку від 29.09.2011 року №1376.

Всі окреслені напрямки використання резервного капіталу є важливими і цінними для підприємства.

Звичайно, опосередковано резервний капітал буде використовуватись на погашення заборгованості у разі ліквідації товариства тощо. Але тільки опосередковано, так як погашатись зобов'язання будуть конкретними активами (наприклад, грошовими коштами). Тому і немає потреби зазначати це як окремий напрям використання. Завдяки наявності такої статті в капіталі - підприємство до моменту ліквідації 
збереже частину активів від розподілу і виплати учасникам, а тому вони i зможуть бути використані на виплату боргів перед кредиторами.

Нерозуміння суті і призначення резервного капіталу призводить до того, що існують думки про необхідність відкладання грошових коштів на окремому рахунку (як варіант - депозитному) при формуванні резервного капіталу. На нашу думку, це знову ж таки помилково. Грошові кошти і резервний капітал не мають між собою прямого і чіткого взаємозв'язку. Сформований резервний капітал аж ніяк не означає, що паралельно десь підприємство відклало грошові кошти. Грошові кошти - це активи, а резервний капітал - власне джерело фінансування, щодо якого точно не відомо, в які саме активи втілене. Наявність резервного капіталу серед власних джерел капіталу тільки означає, що на таку ж суму підприємство має активи і вони залишаться до моменту ліквідації підприємства. Переклавши частину власного капіталу 3 нерозподіленого прибутку в резервний капітал, підприємство гарантує своїм кредиторам, що рівновелика частина активів буде збережена (учасники не зможуть іiі вилучити у вигляді дивідендів чи розподілу прибутку), а тому ці активи можуть бути використані на погашення заборгованості перед ними. Не погоджуємось і 3 тим, що перерозподіл нерозподіленого прибутку на резервний капітал вилучає ці кошти 3 обороту [7]: «...формування вимагатиме вилучення 3 обороту суб'єкта господарювання частини прибутку ... у вигляді реінвестування прибутку у спеціальний резерв товариства».

Резервний капітал виступає власним джерелом фінансових ресурсів, що забезпечує безперервну роботу підприємства i гарантує дотримання інтересів кредиторів. Звичайно підприємство може існувати і без резервного капіталу, але в цьому випадку для кредитора можлива ситуація, що на момент ліквідації підприємства учасники попередньо максимально вилучать активи у вигляді розподілу прибутків. Кредиторам же, хоч вони i мають першочерговість виплат перед учасниками, заборгованість виплачена не буде, оскільки для цього у підприємства не вистачить активів. Наявність резервного капіталу підвищує очікування кредиторів на погашення заборгованості перед ними, а тому збільшує довіру кредиторів до даного підприємства. Чим більша величина резервного капіталу - тим більша довіра. I не має значення, у вигляді яких саме активів вони перебуватимуть на момент ліквідації. Головне - щоб вони були. Якщо вони будуть не у вигляді грошових коштів - не страшно, запаси, основні засоби, нематеріальні активи i т.д. підприємство зможе продати, а за рахунок виручених грошових коштів розрахуватись 3 кредиторами. В будь-якому випадку розрахунок 3 кредиторами проводитиметься активами, а не резервним капіталом.

Резервний капітал для підприємства $є$ тим фундаментом, який повинен компенсувати ризики діяльності підприємства. Це стосується і ризиків неефективної роботи чи інших чинників, що призводять для збитковості роботи підприємства. Якщо ці збитки разові, випадкові чи перекриваються попередніми чи наступними прибутковими роками, то значних проблем підприємству вони не мали б принести. Але якщо збитки підприємство зазнає з року в рік, внаслідок чого непокриті збитки вже зменшують величину власного капіталу, тут вже підприємству слід враховувати наступні норми Цивільного кодексу: ч 4. ст. 144 для товариств 3 обмеженою відповідальністю і ч. 3. ст. 155 для акціонерних товариств - «Якщо після закінчення другого чи кожного наступного фінансового року вартість чистих активів товариства ... виявиться меншою від статутного капіталу, товариство зобов'язане оголосити про зменшення свого статутного капіталу i зареєструвати відповідні зміни до статуту в установленому порядку, якщо учасники не прийняли рішення про внесення додаткових вкладів. Якщо вартість чистих активів товариства стає меншою від визначеного законом мінімального розміру статутного капіталу, товариство підлягає ліквідації». Якщо товариству 3 обмеженою відповідальністю ліквідація в будь-якому випадку не загрожує (для них не визначено мінімальний розмір статутного капіталу), то для акціонерних товариств може постати таке питання гостро. В цьому випадку товариство може прийняти рішення про покриття збитків за рахунок резервного капіталу. В результаті цього покращиться структура власного капіталу, сума непокритих збитків зменшиться чи взагалі стане нульовою. Але величина власного капіталу (чистих активів) при цьому не зміниться. Аналогічно як і поповнення резервного капіталу теж на величину власного капіталу не впливає. В результаті цих операцій здійснюється тільки перерозподіл в межах чистих активів.

3 огляду на співзвучність часто в публікаціях зустрічається віднесення до складу резервного капіталу всіх можливих резервів, що їх створює підприємство: витратних та оціночних [3]. До витратних відносять резерви на оплату відпусток працівників, на гарантійний ремонт і гарантійне обслуговування. Оціночними називають резерви 
по сумнівних боргах, резерви під зниження вартості матеріальних цінностей. На наше переконання це неправильно. Всі три позиції $\epsilon$ абсолютно різними категоріями, хоча звично їх всіх називають резервами.

Витратні резерви доречніше б було називати забезпечення. Вони формуються відповідно до Положення (стандарту) бухгалтерського обліку 11 «Зобов'язання», оскільки є різновидом зобов'язання. Так як вони відносяться до позикового капіталу, відповідно не можуть включатись до елемента власного - резервний капітал.

Ti ж резерви, що названі автором оціночними, створюються з метою уточнення вартості певних активів. Так, резерв сумнівних боргів створюється 3 метою відображення достовірної вартості активу - дебіторська заборгованість. В балансі дебіторська заборгованість відображається за чистою реалізаційною вартістю, яка розраховується як різниця між сумою заборгованості дебіторів i величиною нарахованого резерву сумнівних боргів. Резерви під зниження вартості матеріальних цінностей можуть розраховуватись як по необоротних активах, так і по запасах, але так само з метою недопущення завищення їх вартості в балансі. Так як вони коригують вартість активів, тому теж не можуть мати жодного відношення ні до власного капіталу загалом, ні до резервного зокрема.

Висновки i перспективи подальших досліджень Проаналізувавши економіко-правове забезпечення процесу формування i використання резервного капіталу було встановлено, що зобов'язані створювати його не всі підприємства. Але враховуючи переваги, які дає підприємству його існування, переконані, що він буде доречним багатьом. Наявність резервного капіталу підвищує фінансову стійкість підприємства, зменшує ймовірність банкрутства, підвищує платоспроможність. Наявність додаткового джерела фінансування додає впевненість кредиторам в тому, що підприємство виконає свої зобов'язання перед ними. Чим більша сума зарезервована, тим більшу суму збитків вона зможе покрити і тим більшу маневренність одержує керівництво підприємства. Резервний капітал виступає своєрідним запасом фінансової міцності підприємства. Разом 3 тим необхідні подальші дослідження для визначення оптимальної величини резервного капіталу, оскільки існуючий підхід прив'язки у відсотковому співвідношенні до статутного капіталу є доволі суперечливим.

\section{ПЕРЕЛІК ВИКОРИСТАНИХ ДЖЕРЕЛ}

1 Воськало Н. Проблеми формування та використання резервного капіталу / Н. Воськало, В. Воськало // Вісник національного університету «Львівська політехніка». Серія: Менеджмент та підприємництво в Україні: етапи становлення та проблеми розвитку. - 2009. - №647. - С. 305-309. [Електронний ресурс]. - Режим доступу : http://ena.lp.edu.ua/bitstream/ntb/2765/1/52.pdf

2 Господарський кодекс України від 16 січня 2003 р. № 436-IV з наступними змінами і доповненнями // Офіційний Вісник України. - 2003. - № 11. - С. 462.

3 Коркушко О.Н Класифікаційні види власного капіталу, як об’єкта обліку / О.Н. Коркушко // Сталий розвиток економіки. - 2013. -- №4. -- С. 262-265. [Електронний ресурс]. - Режим доступу : http://nbuv.gov.ua/UJRN/sre_2013_4_57

4 Про акціонерні товариства : Закон України від 17 верес. 2008 р. №514-VI / Верховна Рада України// Урядовий кур’єр. - 2008. - 29 жовт. (№ 202). - С. 5-12

5 Про господарські товариства: Закон України від 19 вересня 1991 р. № 1576-XII // Відомості Верховної Ради України. - 1991. - № 49. - С. 682.

6 Цивільний кодекс України від 16 січня 2003 р. № 435-IV // Відомості Верховної Ради України. - 2003. № 40-44. - С. 356 .

7. Цюцяк І.Л. Економіко-правовий аспект обліку резервного капіталу в системі управління / І.Л. Цюцяк // Облік і фінанси АПК № 32011 [Електронний ресурс]. - Режим доступу : http://magazine.faaf.org.ua/ekonomikopravoviy-aspekt-obliku-rezervnogo-kapitalu-v-sistemi-upravlinnya.html

\section{REFERENCES}

1. Voskalo N. (2009) Problemy formuvannia ta vykorystannia rezervnoho kapitalu [ Problems of formation and use of reserve capital]/Voskalo N., Voskalo V. // Visnyk natsionalnoho universytetu "Lvivska politekhnika". Seriia: Menedzhment ta pidpryiemnytstvo v Ukraini: etapy stanovlennia ta problemy rozvytku [Bulletin of Lviv Polytechnic National University. Series: Management and Entrepreneurship in Ukraine: stages of formation and development problems]. - (pp. 305-309). [In Ucrainian].

2. (2003) Hospodarskyi kodeks Ukrainy vid 16 sichnia 2003 r. № 436-IV z nastupnymy zminamy i dopovnenniamy [Commercial Code of Ukraine dated January 16, 2003 No. 436-IV, with subsequent amendments and supplements] // Ofitsinyi Visnyk Ukrainy [Official Bulletin of Ukraine]. - (p. 462). [In Ucrainian]. 
3. Korkushko O.N. (2013) Klasyfikatsiini vydy vlasnoho kapitalu, yak ob'iekta obliku [Classification Types of Equity Capital as Accounting Object] / Korkushko O. N. // Stalyi rozvytok ekonomiky [Sustainable Economic Development]. - (pp. 262-265). [In Ucrainian].

4. (2008) Pro aktsionerni tovarystva : Zakon Ukrainy vid 17 veres. 2008 r. №514-VI [On Joint-Stock Companies: Law of Ukraine dated September 17, 2008 No. 514-VI] / Verkhovna Rada Ukrainy [Verkhovna Rada of Ukraine]// (pp. 5-12) - Uriadovyi kurier [In Ucrainian].

5. (1991) Pro hospodarski tovarystva: Zakon Ukrainy vid 19 veresnia 1991 r. № 1576-XII [On Business Associations: Law of Ukraine dated September 19, 1991 No. 1576-XII] // Vidomosti Verkhovnoi Rady Ukrainy [Information from Verkhovna Rada of Ukraine]. - (p. 682). [In Ucrainian].

6 (2003) Tsyvilnyi kodekc Ukrainy vid 16 sichnia 2003 r. № 435-IV [Civil Code of Ukraine dated January 16, 2003 No. 435-IV] // Vidomosti Verkhovnoi Rady Ukrainy [Information from Verkhovna Rada of Ukraine]. - (p. 356). [In Ucrainian].

7. Tsiutsiak I.L.(2011) Ekonomiko-pravovyi aspekt obliku rezervnoho kapitalu v systemi upravlinnia [Economic and Legal Aspect of Reserve Capital Accounting in the Management System] / Tsiutsiak I.L. // Oblik i finansy APK № 32011 [Accounting and Finance of AIC No. 3 2011] [In Ucrainian].

Одержано 15.03.2018 p. 